\title{
MONSOON DISTURBANCES OVER SOUTHEAST AND EAST ASIA AND THE ADJACENT SEAS
}

\author{
C.-P. Chang \\ Department of Meteorology \\ Naval Postgraduate School, Code MR/Cp \\ Monterey, CA 93943 \\ Telephone 408-656-2840, e-mail cpchang@nps.navy.mil
}

Award \# N0001497WR30019

\section{LONG TERM GOALS}

To study weather disturbances over the Southeast and East Asian monsoon region and its adjacent seas using Navy research and operational analysis and forecast models. The primary goal is to advance our understanding of the weather-producing systems in the region, in order to improve forecast capabilities. In the process we will assess the skill and characteristics of the models in representing and forecasting these disturbances and find clues that may be useful for model improvement efforts.

\section{OBJECTIVES}

The objectives are to study the structure and the dynamic and thermodynamic properties of the synoptic and meso scale weather-producing disturbances in the Southeast and East Asian monsoon region, the South and East China Seas, and the western Pacific and the eastern Indian Ocean. The study focuses on the development and evolution mechanisms of these disturbances and their interactions with the different stages of the large-scale monsoons in the atmosphere and ocean, in particular the convective "Mei-yu" disturbances ("Changma" in Korea and "Baiu" in Japan) that developed following the onset and reinforcement of the southwest monsoon in the South China Sea. This work is supported by ONR Marine Meteorology.

\section{APPROACH}

Observational studies/Data analysis: Use archived gridded data from global NWP outputs and satellite data to determine the structure of meso and synoptic disturbances in various local regions. Use Navy's MOODS data to study sea surface temperature changes during the monsoon onset. Use potential vorticity diagnostic tools in the case studies of the "Mei-yu" disturbances. Use composite and principal component approaches to perform statistical analysis of the data.

Numerical modeling: Perform sensitivity and simulation studies of the observed monsoon disturbances with Navy's regional research and operational models. Models initialized with Navy and ECMWF global fields. The sensitivity studies look at both impacts of 


\section{Report Documentation Page}

Form Approved

OMB No. 0704-0188

Public reporting burden for the collection of information is estimated to average 1 hour per response, including the time for reviewing instructions, searching existing data sources, gathering and maintaining the data needed, and completing and reviewing the collection of information. Send comments regarding this burden estimate or any other aspect of this collection of information,

including suggestions for reducing this burden, to Washington Headquarters Services, Directorate for Information Operations and Reports, 1215 Jefferson Davis Highway, Suite 1204, Arlington

VA 22202-4302. Respondents should be aware that notwithstanding any other provision of law, no person shall be subject to a penalty for failing to comply with a collection of information if it

does not display a currently valid OMB control number.

1. REPORT DATE

30 SEP 1997

4. TITLE AND SUBTITLE

Monsoon Disturbances Over Southeast and East Asia and the Adjacent

Seas

6. $\operatorname{AUTHOR}(\mathrm{S})$

7. PERFORMING ORGANIZATION NAME(S) AND ADDRESS(ES)

Naval Postgraduate School,Department of

Meteorology,Monterey,CA,93943

9. SPONSORING/MONITORING AGENCY NAME(S) AND ADDRESS(ES)

3. DATES COVERED

00-00-1997 to 00-00-1997

5a. CONTRACT NUMBER

5b. GRANT NUMBER

5c. PROGRAM ELEMENT NUMBER

5d. PROJECT NUMBER

5e. TASK NUMBER

5f. WORK UNIT NUMBER

8. PERFORMING ORGANIZATION

REPORT NUMBER

10. SPONSOR/MONITOR'S ACRONYM(S)

11. SPONSOR/MONITOR'S REPORT

$\operatorname{NUMBER}(S)$

12. DISTRIBUTION/AVAILABILITY STATEMENT

Approved for public release; distribution unlimited

13. SUPPLEMENTARY NOTES

14. ABSTRACT

15. SUBJECT TERMS

16. SECURITY CLASSIFICATION OF:

a. REPORT

unclassified b. ABSTRACT

unclassified c. THIS PAGE

unclassified
17. LIMITATION OF ABSTRACT

Same as

Report (SAR)
18. NUMBER 19a. NAME OF

OF PAGES RESPONSIBLE PERSON

4 
enhanced radiosonde data reports and effects of topography and diabatic heating. The results are analyzed with vorticity and vertical motion diagnostic tools.

Field experiment: Participate in the international South China Sea Monsoon Experiment. The field phase with enhanced atmospheric and oceanographic observations over the South China Sea and its vicinity is scheduled for late spring and early summer 1998. The field phase data, together with data collected from the concurrently held GEWEX Asian Monsoon Experiment, will be used both for the observational data analysis and the modeling studies, as well as to conduct validation for the models' analysis and parameterization schemes.

\section{WORK COMPLETED}

1. A data impact sensitivity study on the numerical modeling of East Asian monsoon disturbance using Navy's operational regional model (NORAPS). All experiments were initiated with the ECMWF analysis, but different amounts of a research data set based on a post-operational collection of Chinese radiosonde data were used to enhance the initial field. The sensitivity study was accomplished by comparing the results of the different experiments in forecasting a severe summer monsoon disturbance that propagates from eastern China to the East China Sea and Korea in July 1991.

2. A diagnostic study of an East Asian monsoon disturbance. This was a study of the basic dynamics of severe Mei-Yu disturbances over the East China Sea during northern summer. Inversion techniques of linear and nonlinear potential vorticity were used to diagnose the structure and intensification mechanisms of selected disturbances, for comparison with future NORAPS and COAMPS simulations.

3. Analysis and modeling of the atmosphere-sea interaction over the South China Sea during transition of monsoon from northern winter to northern summer. This work is done in collaboration with Prof. Peter Chu of NPS. Navy's Master Oceanographic Observation Data Set was used to identify a warm-core eddy in the upper South China Sea west of the Philippines. The evolution of the eddy appear to be related to the development of the monsoon.

4. Examination of the lateral boundary problem of Navy's operational regional models. These problems occur primarily in the tropical Asia - Western Pacific - Indian Ocean monsoon region. For the regional models (NORAPS and COAMPS) the lateral boundary problem appears in 24 or 48 hour forecasts of the geopotential height and mean sea level fields (therefore also the temperature field), where grid points near the lateral boundaries show isoplethes that are parallel to the boundary. Through discussions with NRL scientists Drs. C. S. Liou and Melinda Peng, we performed several experiments trying to find the source of the problems.

5. Planning of SCSMEX Field Experiment. Continued the national and international coordination and planning activities for the field phase of South China Sea Monsoon 
Experiment, and its coordination with the GEWEX Asian Monsoon Experiment, both scheduled for late spring and summer of 1998.

\section{RESULTS}

1. The data impact sensitivity study shows the importance of post-operational radiosonde data. Forecasts of the July 1991 heavy rainfall case initiated by the advanced $1.125^{\circ} \mathrm{X}$ $1.125^{\circ} \mathrm{ECWMF}$ analysis alone underestimates the heavy rainfall over East China Sea, Yellow Sea and Korea (Chang and Yi, 1997).

2. The potential vorticity diagnosis of a intense East Asian summer monsoon case shows that in addition to the condensation latent heat release due to convection, "tropopause folding" can be another important factor for these systems, particularly in the mature stage as the disturbances move off east coast of China. The folding and the development in middle troposphere leads to a strong vertical coupling and lower level cyclogenesis that sustains the intensification of the disturbance in the East China Sea-Korea-Japan region (Chang and Hou, 1997).

3. The development phase of the warm-core eddy in this hypothesis is tested by using the Princeton Ocean model. This eddy occurred before the development of the northern summer monsoon and disappeared afterward. We propose that this eddy is a result of the radiative warming during spring and the downwelling due to the anticyclonic forcing at the surface. Our hypothesis suggests an air-sea feedback scenario that may explain the development and withdrawal of the summer monsoon over the SCS.

4. In both hemispheres the lateral boundary problem in the Navy regional models becomes more conspicuous when the domain is closer to the equator. Modifications of source codes in defining the Coriolis parameter, the treatment of the initial temperature, the coefficients for variational adjustment of temperature and height, and the interpolation of pressure did not resolve this problem..

5. Participated in the SCSMEX Organizing Committee meeting November 1997, the Science Planning Meeting March 1997 and Science Steering Committee Meeting September 1997. Revised the science plan and the implementation plan for the field phase of SCSMEX. Coordinated radiosonde, ship and radar plans among U.S., Mainland China, Taiwan, Australia and ASEAN countries.

\section{IMPACT}

The research on the East Asian monsoon disturbances provided better understanding of these heavy weather systems during the onset and active stages of the monsoon. This leads to better design of the field experiments and future modeling efforts. Continuous interaction with NRL scientists on the application of Navy models provided user feedback to the modelers on the model performance and special characteristics for the South and East China Sea, Japan Sea, Yellow Sea, eastern China, Japan and Korea region. 


\section{TRANSITIONS}

N/A

\section{RELATED PROJECTS}

Collaboration with Prof. Peter Chu's project "Shallow Water Analysis and Forecast System for the South China Sea", under ONR Naval Ocean Modeling and Prediction Program.

\section{REFERENCES}

Chang, C.-P., J. M. Chen., P. A. Harr and L. E. Carr, 1996: Northwestward-Propagating Wave Patterns Over the Tropical Western North Pacific During Summer. Monthly Weather Review, 124, 2245-2266

Chu, P. C. and C.-P. Chang, 1997: South China Sea Warm Pool in Boreal Spring. Advances in Atmospheric Sciences, 14, 195-206.

Chang, C.-P. and Lan Yi, 1997: Forecast of A Severe East Asian Monsoon Disturbance Using Navy's Operational Regional Model: A Sensitivity Study on Initial Data Analysis, Pre-Prints, First International Workshop on Monsoons, Feb 1997, Denpasar, Indonesia, World Meteorological Organization, Geneva 14-18.

Chang, C.-P. and S. C. Hou, 1997: The Development of a Mei-yu Disturbance during East Asian Monsoon, Pre-Prints, First International Workshop on Monsoons. Feb 1997, Denpasar, Indonesia, World Meteorological Organization, Geneva., 19-22.

Chu, P. C. H. C. Tseng, C.-P. Chang and J.M. Chen, 1997: South China Sea warm pool detected in spring from the Navy's Master Oceanographic Observational Data Set (MOODS) J. Geophysical Research, 102 C7, 15761-15771. 